\title{
On some empty categories in Icelandic and Latvian (PRO and pro)
}

\section{Par dažiem formāli nerealizētiem komponentiem islandiešu un latviešu valodā (PRO un pro)}

\author{
Dens Dimiņš \\ University of Iceland \\ Faculty of Icelandic and Comparative Cultural Studies, \\ Sæmundargötu 2, 101 Reykjavik, Iceland \\ E-mail:ddeens@gmail.com
}

\begin{abstract}
Empty categories are abstract elements in the deep sentence structure. This paper deals with the pronominal null subjects - big PRO and small pro. The article provides definitions and refers to further theoretical discussion of these empty categories from a generative perspective. Null subjects are relevant to the principle of the economy of language resources, Universal Grammar, and are certainly present in all languages. Two Indo-European languages are selected for comparison, a Germanic language (Icelandic) and a Baltic language (Latvian). There are similar patterns in PRO and small pro constructions in Icelandic and Latvian, which suggests some surface-level structural similarity between the two languages. However, despite the overlaps, there are also significant differences, especially with regard to case government with infinitivals, the use of the dummy subject and the explicit (overt) pronoun use in the imperative. The main part of this paper discusses the types and the classification of the constructions featuring big $P R O$ and small pro in both languages. Among the infinitive constructions with $P R O$ are (1) the referential or controlled, (2) uncontrolled or arbitrary, and (3) expletive construction. There are eight little pro constructions with the verb in finite form: (1) the impersonal construction, (2) the impersonal-passive construction, (3) the extraposition construction, (4) the imperative/optative, (5) the elliptical construction, (6) elliptical answers/remarks, (7) stage directions and (8) exclamations. Further, there are three less marginal constructions, namely, (1) the impersonal present participle construction, (2) the impersonal modal construction and (3) the ergative construction.
\end{abstract}

Keywords: PRO, pro, null forms, empty categories, Icelandic, Latvian, generative grammar, deep structure, surface structure.

\section{Introduction - framework - definitions}

1. The paper examines Icelandic and Latvian with regard to the use of implicit (covert) subject pronouns, namely, PRO and pro, in both languages. The outlined directions by no means reveal a complete picture, as the topic is rather extensive. In Icelandic syntax, there is also a discussion about pronominal, coreferential "null object" (Thráinsson 2007, 479) in coordination structures of

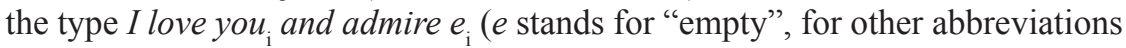
see the corresponding list at the end of the paper). This paper, however, is limited only to the null subjects. 
An Icelandic example is normally given first, and followed by a Latvian one. The default unmarked verb tense is the present for both languages. If nothing is marked with a verb, it is in the infinitive. The default third person verb number in Latvian is the singular or plural (unmarked). The default number of the nominals is the singular, the default case is the nominative (unmarked). Gender is only marked sporadically, insofar as it is relevant to show agreement. Indeclinable parts of speech are mostly unmarked. All translations of the Latvian examples are done by the author.

2. The following definitions are given:

2.1. PRO (abbreviation for "pronominal") or big PRO is an "unpronounced subject of infinitivals" (Poole 2011, 96) or "nonlexical infinitival subject" (Sigurðsson 1992, 179) or "can appear in the specifier of non finite TP" (Carnie 2013, 439). In the standard Government and Binding (GB) theory, e. g., by Chomsky 1982 and Rizzi 1986, PRO is ungoverned (has no case) and can be both anaphoric (controlled) or pronominal (free or arbitrary. However, there is also a view that only controlled PRO exist, see the discussion under item 6 of this Introduction.

\subsubsection{Anaphoric $P R O$}

(1) Við báðum

$$
\text { Jón }{ }_{\mathrm{i}} \quad \text { að } \mathrm{PRO}_{\mathrm{i}}
$$

búa til

nýjar

setningar.

we ask.PRET.PL.1 Jón.ACC to make

'We asked Jón to formulate new sentences.'

(2) Mēs lūdzām Jāni(m) ${ }_{\mathrm{i}} \quad \mathrm{PRO}_{\mathrm{i}}$ izveidot jaunus teikumus. we ask.PRET.PL.1 Jānis.DAT/ACC make new sentence.ACC.PL 'We asked Jānis to formulate new sentences.'

\subsubsection{Pronominal $P R O$}

(3) मаð er erfitt að PRO búatil nýjar setningar. it is difficult to make new sentence.ACC.PL

'It is difficult to formulate new sentences.'

(4) Ir grūti PRO

veidot jaunus

teikumus.

is difficult make new sentence.ACC.PL

'It is difficult to formulate new sentences.'

2.2. There is also a null (zero) pronominal element, which is usually referred to as "little pro" (Poole 2011, 234) or "baby pro" (Carnie 2013, 450). This element can be found in a subject position of a finite clause and has case. An example with pro, where it has the nominative case (optative constructions):

(5) pro Förum.

go.PL.1

'Let's go.' 
(6) pro Braucam.

go.PL.1

'Let's go.'

2.3. The theory of control is concerned with the choice of antecedents of PRO (Chomsky 1982, 7). If no antecedent is available, the control is considered arbitrary (Růžička 1999, 13).

2.4. Binding is a syntactic relation, where $\mathrm{A}$ binds $\mathrm{B}$ if and only if A c-commands $\mathrm{B}$, and $\mathrm{A}$ and $\mathrm{B}$ are coindexed. $\mathrm{A}$ is the binder, $\mathrm{B}$ is the bindee (Carnie 2013, 157).

2.5. Government is a syntactic relation, where Node $A$ governs node $B$, if $A$ c-commands B, and there is no node $\mathrm{G}$ such that $\mathrm{G}$ is c-commanded by A, and $\mathrm{G}$ asymmetrically commands B (Carnie 2013, 130).

2.6. The Empty Category Principle is an extension of the notion of government. Government, or the absence of government, is involved in the distribution of null pronouns (Cowper 1992, 15, 102). This involves, on the one hand, a relation between the lexical head and its complements, and, on the other, the inflection element and its subject, also involving features such as person, gender and number (agreement) and tense (plus or minus).

3. In a broader perspective, $P R O$ and pro are instances of implicit subject anaphors or pronouns in the deep structure (D-structure). These are said to have left traces in the surface structure (S-structure) (Poole 2011, 152). The $D$-structure of a sentence is therefore fully recoverable from the S-structure. This allows a semantic interpretation or logical form recovery, as Chomsky calls it (Chomsky 1988, 17), to be done purely on the basis of S-structure. The empty categories are not a part of morphemic inventory in syntax, because their meaning is inferred at a later stage (it is implicit), but are well part of the syntactic one.

4. In Icelandic syntactic literature, it has been argued that $P R O$ is essentially the same phenomenon as pro (Sigurðsson 1992, 179). According to Sigurðsson $(1990,37)$, the $P R O /$ pro distinction does not work in Icelandic, because there is evidence that $P R O$ is both case-marked and governed. This argument is taken up by Carnie (2013, 452-453). He admits that with regard to verbs assigning quirky cases one can hypothesize that floated quantifiers must agree with the noun they modify in terms of case:

(7) Strákarnir vonast til að PRO leiðast ekki öllum iskóla. boy.PL.DEF hope.PL.3 for to bore.INF.REFL not all.DAT.PL. in school.DAT 'The boys hoped not to be bored all of them at school.'

It is apparent that the same problem arises in Latvian:

(8) Zēniem bija svarīgi PRO būt saprastiem. boy.DAT.PL was important be understood.PTCP.PASS.DAT.PL 'For the boys, it was important to be understood.' 
This poses a problem to the Chomskian claim that $P R O$ never gets the case but is of little relevance for the purposes of this article, so the distinction and use of $P R O$ for subjects in non-finite clauses and pro in finite clauses will be maintained.

5. Later (in the early 1990s and thereafter), the GB theory was further developed in the Minimalist Program by Chomsky himself (Chomsky 1995) and others, as well as in the framework of Distributed Morphology (Halle \& Marantz 1993). Some proposals envisaged to eliminate pro as an independent theoretical construct in the null subject parameter and to revise and parametrize the extended projection principle (Camacho 2013, 6, and the sources quoted there). This paper cannot provide a detailed elaboration on this topic.

6. In Latvian syntactic literature, there is a discussion about nullforma (null form) as formālas izpausmes trūkums pretstatā formāli izteiktiem paradigmas elementiem ('absence of formal expression as opposed to formally expressed paradigmatic elements') (Skujina 2007, 265). In the Latvian translation (2012) of the Lithuanian syntax manual Bendrosios sintaksés pagrindai ('Foundations of General Syntax') by Holvoet (2009), the following terms are used: (1) for $P R O$, virsteikuma argumenta kontrolettais nulles subjekts 'the controlled null subject of the main clause'; (2) for little pro, nulles subjekts, atbilst anaforiskam personas vietniekvārdam 'a null subject corresponding to an anaphoric personal pronoun' (Holvūts 2012, 141). This terminology is consistent with the general idea of the generativist thought that "all $P R O$ are controlled if apparently uncontrolled $P R O$ actually has a hidden controller [..]" (Chomsky/Lasnik 1993, 20), or, "so-called $P R O_{\text {arb }}$ is really a subcase of controlled $P R O$ " (Kayne 1991). There have also been earlier publications on infinitive constructions in Latvian, for instance, by Kārkliņš (1976) and Freimane (1985).

\section{Infinitive constructions with pronominal null forms}

In Icelandic, there are three types of infinitive constructions with pronominal null forms - referential or controlled, uncontrolled or arbitrary and expletive (Sigurðsson 1990, 35-82).

1. First, the referential constructions (also called anaphoric). These are sentences of the type " $\mathrm{X}_{\mathrm{i}}$ expects $\mathrm{PRO}_{\mathrm{i}}$ to win":

$\begin{array}{llllll}\text { (9) Við sögðum } & \text { honum að PRO vera ekki svona } & \text { ergilegur/ergilegum } \\ \text { we tell.PRET.PL.1 he.DAT to } & \text { be not so } & \text { annoyed.ADJ.NOM/DAT }\end{array}$

'We told him not to be so annoyed.'

Sigurðsson points out that acceptability of non-nominative agreement can sometimes depend on lexical items (Sigurðsson 1990, 46, footnote 14). While in the previous example both cases (both the nominative and dative) are considered acceptable, only the nominative is viewed as grammatical in (10):

$\begin{array}{llllll}\text { (10) Við sögðum } & \text { honum að PRO } & \text { vera } & \text { ekki } & \text { svona } & \text { latur. } \\ \text { we tell.PRET.PL.1 } & \text { he.DAT to } & \text { be } & \text { not } & \text { so } & \text { lazy.NOM.M }\end{array}$

'We told him not to be so lazy.' 
The case marking on the adjective, when it is used in an infinitive construction, depends on the structure of the phrase and the government (Rektion) of the verb (preceding or, in some instances, following $P R O$ ), as we can see from the following examples:
(11) Strákarnir
vonast til að $\mathrm{PRO}$
verða
aðstoðaðir.
boy.PL.M.DEF hope.PL.3 for to become,
assisted.PRET.PTCP.PL.M
'The boys hoped that somebody would help them.'

Here $P R O$ is quite clearly co-referential with the subject and would be assigned the nominative plural, as is the case with the agreeing participle. Compare a passive variant of the same phrase:
(12) Strákarnir
vonast
til
boy.PL.M.DEF
hope.PL.3 for to
að PRO verða
hjálpað.
'The boys hoped that somebody would help them.'

The form hjálpað after the auxiliary verb is indeclinable and is viewed as supine (sagnbót), i.e. a nominal form, which is identical with the neuter past participle nominative and accusative form (Thráinsson 2007, 11). In Icelandic, supine is used in the passive, when a transitive verb in the corresponding active construction takes a non-accusative object (often dative, in rare cases, genitive). In (12), the verb hjálpa takes the dative. Therefore, in the passive, dative is conserved and a non-agreeing participle form is used (hjálpað). This leads to hypothesize that $P R O$ in (12) receives the dative case. Another example with the dative in the passive:

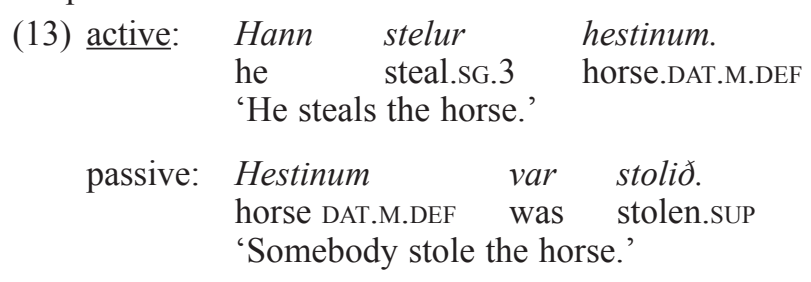

This dative in the passive voice can be explained by a certain functional applicative formation which moves the head of a subject or adjunct to another head position and incorporates the dative (or genitive), according to Baker's 1988 Theory of Incorporation (Baltin \& Collins 2001, 115-118). However, if there is an accusative object, it is transformed into a nominative object and an agreeing participle is used, just like in many other languages, cf. Latin, Puer librum ${ }_{\text {ACC }}$ legit 'a boy reads a book' vs. Liber ${ }_{\mathrm{NOM}}$ lectus est 'a book is read':
(14) active:
Deir seldu
bókina.
they.M sell.PRET.PL.3 book.ACC.F.DEF
'They sold the book.'
passive: Bókin var seld.
book.NOM.F.DEF was sold.PAST.PTCP.NOM.F
'The book was sold.'

As to (11)-(12), in standard present day Latvian such infinitivals would normally not be possible and a subordinate clause would be inserted. This is 
because vonast til 'expect, hope' in Icelandic allows for an infinitival complement (IP), while the Latvian verb cerēt 'to hope' takes a CP and the pronoun is explicit:

However, on a second thought, in special cases, for instance, in a religious context imbued with archaic Biblical syntax, an infinitival complement to the verb cerèt in Latvian is conceivable:
(16) Zèni
cer PRO tapt
atpestīti.
boy.PL.M hope. 3 become
'The boys hope to be saved.'
saved.PTCP.PASS.PL.M

2. Second, there is the uncontrolled or arbitrary PRO. In Icelandic, the null elements mostly occur in a non-initial position but in Latvian they also occur in an initial position:
(17) Pað er hollt PRO að synda.
it is healthy to swim
'It is healthy to swim.'
(18) PRO Peldèt ir veselīgi. swim is healthy
'It is healthy to swim.'

An example with $P R O$ in a non-initial position:
(19) Smagajiem
tur PRO ne-izbraukt.
trucks.DAT/INSTR.PL there not-get_through.NEG-INF
'The trucks would not get through.'

This example is particularly interesting because of case ambiguity (syncretism dative/instrumental) and polarity issues. The absence of the negation particle renders the sentence ungrammatical (*Smagajiem tur izbraukt) and the same happens if the adverb is negated (*Smagajiem ne tur izbraukt). Baylin analyses a similar Russian example (Gruzoviku ne proehat' 'a truck would not pass', Bailyn 2012, 112) and concedes that examples like this one "are in fact bi-clausal, with an unexpressed PRO subject of the verb 'to go through,' while truck is an argument of an unexpressed higher modal." In my view, for Latvian this reading of the agentive scope appears particularly convincing if we assign the instrumental case to the noun smagajiem. The meaning is then likely to be Ar smagajiem tur [šoferiem] neizbraukt, 'with trucks [drivers] are unlikely to pass through'. The Theta role relations in this example are complex. The bi-clausality is another term for secondary predication, see below examples (31)-(32).

If we substitute $P R O$ in (18) with an explicit subject in Latvian, it would receive the dative case:

(20) Cilvēkam/Ikvienam peldèt ir veselìgi. man/anyone.DAT swim is healthy

'It is healthy for everyone to swim.' 
In infinitival impersonal phrases the adjectives linked by means of the copula receive the nominative case in Icelandic but the dative in Latvian. The masculine form is used by default in both languages. The feminine form is used only with an explicit feminine referent and, as far as Latvian is concerned, it is not even always done so.

(21) Раð ergott/mikilvagt að PRO vera duglegur/dugleg.

it is good/important to be diligent.M/F

'It is good/important to be diligent.'

In Icelandic $P R O$ can be rendered explicit by inserting maður (as in German man, French on):

(22) Раð er gott/mikilvagt að maður sé duglegur.

it is good/important that man.M be.SBJV.SG.3 diligent.M

'It is good/important that one should be diligent.'

Here, the adjective in the neuter in Icelandic is used adverbially.

(23) Ir labi/svarīgi PRO būt enerǵiskam/enerǵiskai.

is good/important be energetic.M/F.SG

'It is good/important to be energetic.'

From an interview with psychotherapist Aina Poiša (a woman):

(24)

Q: Jüsu recepte, kā PRO klüt laimìgam?
your recipe how become happy.M
'Your recipe of how to become happy?'

$\begin{array}{lllll}\text { A: Man liekas, } & k a & \text { svarīgāk } & \text { ir piennemt un saprast } & \text { to, } \\ \text { I.DAT seem } & \text { that important.COMP } & \text { is accept and undertand it.ACC }\end{array}$

ka PRO klyūt laimīgam - tas ir process, jo visu mūžu

that become happy.DAT.M it is process because all life.ACC

pro ir jāmācās gan mīlèt, gan būt laimīgam.

is learn.DEB.3 both love and be happy.DAT.M

'It seems to me that it is more important to accept and grasp the fact that becoming happy is a process because all life long one has to learn both to love and to be happy.'

3. Third, the expletive pronominal construction:

(25) Mér virðist PRO vera leiðinlegt hérna.

I.DAT seem.REFL.SG.3 be boring.ADJ.N here

'It seems to me that it is boring here.'

Such a construction with the infinitive is not possible in Latvian. Instead, it is frequent in Latin and a number of Romance languages (accusativus cum infinitivo). In Latvian, a similar or analogous construction is possible with the indeclinable present participle -am-/-ām-. The 1948 Bible edition (a modified Ernst Glück 
translation from 1689) (1. Mozus 1:4, Bihbele 1948, 5) contains the following statement:

(26) Un Dievs redzēja gaismu PRO labu esam. and god see.PRET.3 light.ACC good.ACC.F being.PTCP.INDECL

'And God saw light that it was good.' (Genesis 1:4, The Holy Bible 1834, 5)

Compare the 1966 Bible edition (a more recent translation):

(27) $U$

$\begin{array}{lllllll}\text { Un Dievs } & \text { redzēja } & \text { gaismu, } & k a & t \bar{a} \text { ir laba. } \\ \text { and god } & \text { see.PRET.3 } & \text { light.ACC.F } & \text { that } & \text { it.F is good.F }\end{array}$

A gerund construction similar to the one in (26) is also widely used in Slavic languages, for instance, Russian (Bailyn 2012, 114):

(28) Ivan nashel Sashu PRO chitaya gazetu.

Ivan find.PAST.PTCP.SG.M Saša.ACC.M/F reading.GER newspaper.ACC.F

'Ivan found Sasha reading a newspaper.'

The Russian gerund and the Latvian indeclinable participle function in the same way.

Another pair of examples of the expletive pronominal construction:

(29)Hann virðist PRO vera hroeddur.

he seem.SG.3 be scared.ADJ.M

'He seems to be scared.'

(30) Viņš šksiet PRO (esam) izbijies.

he seem.3 (be.PTCP.INDECL) scared.PAST.PTCP.REFL.SG.M

'He seems to be scared.'

In this last type of structure, the participle is frequently omitted in both languages, and the phrase thus turned into some kind of secondary predication, where one element of a given phrase is connected with two other elements of the same phrase and expresses a feature of a living being, object or phenomenon over the time (Ceplītis et al. 1989, 50):

(31) Viņš izslējās PRO taisns.

he rise.PRET. 3 straight.M

'He straigtened up.'

This phrase means that someone gets up and at the same time also straightens up his posture. The secondary predication can also be seen as a small clause adjunct (Bailyn 2012, 184 et seq., for instance, My nashli ego p'yanym/p'yanogo 'we found him drunk'). A similar Latvian example:
(32) Es atceros
vingu
PRO jaunu.
I remember.REFL.SG.1 he/she.ACC.M/F
young.ACC.M/F
'I remember him/her as a young person.'

This sentence denotes remembrance of the subject in the first person of somebody else (vingu 'him/her', ambiguous) and concomitantly qualifies the person 
remembered as young. This Latvian construction (with or without the participle esam in it, see (30)) is very close to the Latin accusativus cum infinitivo:
(33) Video
eum/eam
juvenem
PRO esse
see.PRES.SG.1 he/she.ACC.M/F
young.ADJ.ACC.M/F
be
'I see him/her to be young.'

\section{Pronominal Constructions with the Verb in Finite Form}

Sigurðsson (1992, 161-162) singles out three main types of pronominal constructions with the verb in finite form that feature little pro. These are the impersonal (often weather) constructions, impersonal passive constructions and the extraposition construction. Thráinsson (2007, 476-482) adds five more: imperative/optative constructions, elliptical constructions, including ones pertaining to postcard, diary and SMS style, elliptical answers or remarks, stage directions and exclamations.

1. First, empty pronominal in Icelandic typically occur with the impersonal - often weather - constructions:

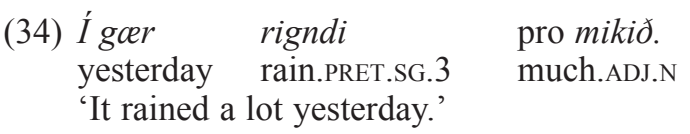

These constructions are, however, not restricted to weather verbs only:

$\begin{array}{lllll}\text { (35) Oft pro er leiðinlegt } & \text { a } & k \text { völdin. } \\ \text { often } & \text { is boring } & \text { in } & \text { evening.ACC.PL.DEF } \\ \text { 'Often the evenings get boring.' } & & \end{array}$

Same constructions occur in Latvian:

(36) Vakar daudz pro lija.

yesterday much rain.PRET.3

'It rained a lot yesterday.'

$\begin{array}{lll}\text { (37) Vakaros } & \text { bieži pro } & \text { ir garlaicīgi. } \\ \text { evening.LOC.PL } & \text { often } & \text { is boring }\end{array}$

'Often the evenings get boring.'

2. Little pro can be found in the impersonal passive constructions:

(38) Stundum var pro hlegið að ráðherranum.
sometimes was laugh.sup at minister.DAT.DEF.M
'Sometimes the minister was laughed at.'

(39) Um petta mál er pro aldrei talað.

about this matter.ACC is never spoken.suP

'This matter is never discussed.'

Same constructions in Latvian in the passive voice:

(40) Bieži vien pro tika smiets par ministru.

often become.PRET.3 laugh.PTCP.PASS about minister.ACC.M

'The minister was often poked fun at.' 
$\begin{array}{lllll}\text { (41) Par } \stackrel{\text { so }}{\text { Paetu }} & \text { nekad pro } & \text { netiek } & \text { runāts. } \\ \text { about this.ACC } & \text { matter.ACC.F } & \text { never } & \text { become.3 } & \text { spoken.PAST.PTCP } \\ \text { 'This matter is never discussed.' } & & & \end{array}$

Sigurðsson $(1992,162)$ notes that such constructions are extremely common in Icelandic and compares their frequency to the German construction with an active pronominal element man. In Latvian they are also common but relatively recent (Kiķauka 1961, 173) and therefore still somehow not entirely natural.

In Latvian, it is possible to express generalized (vispārināts) action by using the third person verb form with the subject null form, where the lexical meaning of the predicate and the context unequivocally show that the agent can only be a human being. Functionally and semantically this usage is parallel to that of the passive voice (Nītiņa \& Grigorjevs 2015, 526, 1161):
(42) Es piezvanī̌̌u, lai jums pro izsniedz
I call.fUT.SG.1 so you.DAT.PL give.3

\section{Marijas Sjuartes tēzu tērpu.}

Mary.GEN.F Stewart.GEN.F wedding.GEN.PL dress.ACC.M

'I will call so that you are given Mary Stewart wedding dress.'

3. Third, there is the extraposition construction:

(43) Ekki er pro alltaf gaman

not is always pleasant.ADJ.INDECL.

(að loera mál).

(to learn language/languages.ACC.SG/PL.N)

'It is not always pleasant (to learn a language/languages).'

Extraposition consists in omission or elimination of heavy constituents or constituents that can be inferred from the context (here - the bracketed part).

Idem in Latvian:

(44) Ne vienmēr pro ir patīkami (mācīties svešvalodas).

not always is pleasant (learn.REFL foreign.language.ACC.PL)

'It is not always pleasant (to learn foreign languages).'

4. There is little pro in imperative/optative constructions.

\subsection{Imperative constructions.}

(45) Farið pro pangað!

gO.IMPER.PL.2 there

'Go there!'

An expletive form Farið pið pangað is also possible and used more often (especially in the contracted form Fariði pangað). The non-expletive forms are limited to a formal or solemn style.
(46) pro

$\begin{array}{lll}\text { Brauciet } & \text { uz } & \text { turieni! } \\ \text { go.IMPER.PL.2 } & \text { to } & \text { there } \\ \text { 'Go there!' } & & \end{array}$


In Latvian, non-expletive construction is used much more often than the expletive one, which denotes emphatic use. An Internet search rendered only non-standard offensive language use with that construction (http:// forestmangonewild.blogspot.com):

(47) Ejiet

tak visi jūs

$u z * * *$

gO.IMPER.PL.2 PART all.PL yOu.PL.2 to

'Why don't you all go to...'

4.2. Optative constructions: see examples (5) and (6) above.

5. Elliptical constructions.

(48) Við vorum svangir og

we were hungry.PL.M and

pro keyptum okkur hamborgara.

buy.PRET.PL.1 us.DAT.PL hamburger.ACC.PL.M

'We were hungry and bought hamburgers.'

(49) Mès bijām noguruši un pro aizgājām uz mājām.

we were tired.PL.M and go.PRET.PL.1 to home.DAT.PL.F

'We were tired and went home.'

In Icelandic, usually the first person pronoun is omitted. However, in postcard, diary and SMS style, the third person pronoun can also occasionally be omitted, resulting in grammatically ambiguous forms (the first or third person syncretism in the past tense singular):
(50) pro Vaknaði
wake.PRET.SG. $1 / 3$ early
'I/he/she/it woke early.'

In Latvian, the form would be ambiguous only in relation to the number and gender, not the person:

(51) Jau

ieradās.

already.ADV come.PRET.SG/PL.3

'He/she/they came already.'

6. There is null subject in elliptical answers or remarks in both Icelandic and Latvian. Thráinsson $(2007,478)$ points out that those are heavily discourse conditioned, i.e. require a conversational context. They mainly occur in the $1^{\text {st }}$ person singular or, more seldom, in the $1^{\text {st }}$ person plural:

$\begin{array}{lll}\text { pro } & \text { Dekki } \quad \text { hann } & \text { ekki. } \\ & \text { know.SG.1 he.ACC.M not } \\ & \text { 'I don't know him.' }\end{array}$
pro Ne-pazīstu
viņu.
no.NEG-know.sG.1 he/she.ACC.M/F
'I don't know him/her.' 
7. pro is used in stage directions:
(54) pro Fer út til hoegri.
go.SG.3 out.ADV to right.ADV
'He/she exits stage right.'
(55) pro Aiziet.
away_go.3
'He/she/they exit.'

8. Finally, pro can be found in exclamations that can be ambiguous morphologically, but pragmatically are always unambiguous:
(56) pro Situr
sit.SG.2/3 just.ADV and drink.SG.2/3 beer.ACC.M
'You are/He/She is just sitting here and drinking beer!'
(57) pro Sēž te un dzer alu!
sit.3 here.ADV and drink.3 beer.ACC.M
'She/He is/They are sitting here and drinking beer!'

\section{Marginal Null-Subject Constructions}

Sigurðsson (1992, 162-163; 199-201) also singles out three more types of less well known null-subject constructions. This is a miscellaneous category where less studied constructions are jumbled together. He mentions the impersonal present participle construction, the impersonal modal construction and the ergative construction.

1. There is the impersonal present participle construction:

(58) Ekki er PRO hloejandi
not is að pessu.
'One should not laugh at this.'

Such necessitive construction does not exist in Latvian. However, a construction that does exist and is semantically close to the above Icelandic structure features the verbal substantive with the suffix $-\check{s}$ an- that roughly corresponds to the Latin gerundivum:

(59) Par šo pro nav ne-kādas smiešanās! about this not-be.3 no-some.GEN.SG.F. laughing.GEN.F

'There is no laughing about this.'

$\begin{array}{cll}\text { (60) pro } & \text { Carthago } \quad \text { nobis delenda } & \text { est } \\ \text { Carthage.SG.F us.DAT.PL destroyable GER.SG.F } & \text { is } \\ & \text { 'Carthage must be destroyed by us.' } & \end{array}$

2. There is the impersonal modal construction:
(61) Parf
pro $а ð$
kaupa
mjólk?
need.PRET.SG.3
to buy
milk.ACC.F
'Should I (we, etc.) buy some milk?' 
The past tense is here used in present meaning in the Icelandic (the so called preterite-present verbs). A parallel construction in Latvian:

(62) pro Vajag nopirkt pienu?

need.3 buy milk.ACC.M

'Should I (we, etc.) buy some milk?'

In Icelandic affirmative sentences, such constructions can have a dummy subject or non-referential expletive (pleonastic, semantically empty) раð. In Icelandic, this overt expletive is restricted to clause-initial position - compare examples in (34) and (61):

(63) मаð rigndi mikið ígaer.

it rain.PRET.SG.3 much yesterday

'It rained a lot yesterday.'

(64)

$\begin{array}{llll}\text { मаð parf } & \text { að kaupa } & \text { mjólk. } \\ \text { it need.PRET.SG.3 to buy } & \text { milk.ACC.F }\end{array}$

'I (we, etc.) should buy some milk.'

In standard Latvian, such sentences are impossible, because the Extended Projection Principle, as formulated by Chomsky, "all clauses must have a subject" (quoted from Poole 2011, 93-94), does not require an explicit subject in impersonal constructions. Insertion of such an expletive subject automatically renders the sentences ungrammatical:

(65) *Vakar tas daudz lija.

(66) *Tas vajag nopirkt pienu.

3. Finally, the ergative construction.

(67) Mér pro líður vel.

I.DAT feel.PRES.SG.3 well.ADV

'I feel well.'

(68) Man pro nāk vēmiens.

I.DAT come.3 vomiting.M

'I feel like throwing up.'

(69) Hana pro langar i köku.

she.ACC long.PRES.SG.3 in cake.ACC.F

'She longs for a cake.'

(70) Tevi pro velk uz kašķi.

thou.ACC.SG pull.3 to squabble.ACC.M

'You feel like squabbling.'

Ergative constructions with the genitive are rare in both languages:

(71) Gunnars pro getur oft $i$ fórnum sögum Gunnar.GeN mention.SG.3 often in old saga.DAT.PL.

'Gunnar is often mentioned in old sagas.' 


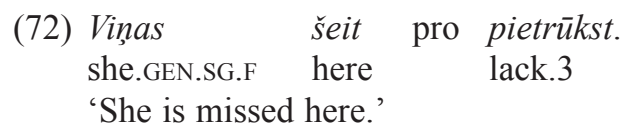

The ergative case marking and Theta role distribution could be concisely explained, as follows: "The logical, underlying subject in an active transitive clause (most typically, Agent) has a Case marker morphologically different from the logical, underlying subject in an (active) intransitive clause, which has the same Case marker as the logical, underlying object (typically, Patient or Theme) in an active transitive clause." (Baltin \& Collins 2001, 347-348). So, in all these examples the default agent marking (the nominative) is replaced by other cases.

\section{Conclusion}

Both languages - Latvian and Icelandic - predictably share similarities in relation to empty categories (null subject forms), insofar as many languages show similar abstract patterns (in the so-called D-structure) but there is bound to be more variation on the surface level. $P R O$ and pro are relevant to universal grammar. The main surface level differences appear in the phrase structure (Icelandic is V2 language but Latvian is not, thus the word order in the latter is freer) and the case governance, for instance, in infinitival impersonal phrases with adjectives linked by means of the copula typically take the nominative case in Icelandic but the dative in Latvian. Both Icelandic and Latvian $P R O$ pose a problem to the Chomskian claim that $P R O$ is always ungoverned (i. e., caseless). There is a striking similarity in the ergative constructions involving little pro. There is no expletive pronoun (dummy subject) in Latvian. There is less variation as to the placement of empty pronominals in Icelandic than there is in Latvian. There is no construction accusativus cum infinitivo in Latvian but there is an equivalent participial construction or, in some cases, a secondary predication construction with a omitted participle of the type es atceros vinu jaunu, 'I remember him/her as young person', or a complementizer phrase (CP) is used instead of the infinitival complement (IP). In some instances, $P R O$ raises issues involving ambiguity of the agentive scope. In some examples, verb and pronoun form syncretism in $P R O /$ pro constructions gives rise to ambiguity in terms of person, number and gender. Formal approaches do not help explain the differences with regard to the possibilities of having overt and non-overt expletive elements in sentence-initial and non-initial position, also, some instances of adjectival case agreement remain perplexing and are likely to be based on semantic rather than formal criteria.

\section{Acknowledgement}

The author of the paper would like to thank Jóhannes Gísli Jónsson from the University of Iceland for clarification on issues related to null subjects, especially for valuable feedback on and discussion of the Icelandic data. 


\section{Abbreviations}

$\begin{array}{llll}\text { ACC } & \text { accusative case } & \text { N } & \text { neuter } \\ \text { ADJ } & \text { adjective } & \text { NEG } & \text { negation, negative } \\ \text { ADV } & \text { adverb } & \text { NOM } & \text { nominative } \\ \text { arb } & \text { arbitrary } & \text { PART } & \text { particle } \\ \text { CP } & \text { complementizer phrase } & \text { PASS } & \text { passive } \\ \text { COMP } & \text { comparative } & \text { PRET } & \text { past tense } \\ \text { D-structure deep structure } & \text { PTCP } & \text { participle } \\ \text { DAT } & \text { dative } & \text { PL } & \text { plural } \\ \text { DEB } & \text { debitive } & \text { PRS } & \text { present tense } \\ \text { DEF } & \text { definite } & \text { pro } & \text { null subject of finite } \\ e & \text { empty } & & \text { phrase (small pro) } \\ \text { F } & \text { feminine } & \text { PRO } & \text { null subject of non-finite } \\ \text { FUT } & \text { future tense } & & \text { phrase (big PRO) } \\ \text { DM } & \text { distributed morphology } & \text { PRON } & \text { pronoun } \\ \text { DP } & \text { determiner phrase } & \text { REFL } & \text { reflexive } \\ \text { GEN } & \text { genitive } & \text { S-structure } & \text { surface structure } \\ \text { GER } & \text { gerund } & \text { SG } & \text { singular } \\ \text { GB } & \text { government and binding } & \text { SBJV } & \text { subjunctive } \\ \text { IMPER } & \text { imperative } & \text { SUP } & \text { supine } \\ \text { INDECL } & \text { indeclinable } & \text { TP } & \text { tense phrase } \\ \text { INF } & \text { infinitive } & / & \text { or } \\ \text { INSTR } & \text { instrumental } & 1 & \text { first person agreement } \\ \text { IP } & \text { infinitival complement } & 2 & \text { second person } \\ \text { M } & \text { masculine } & \text { agreement } \\ & & \text { third person agreement }\end{array}$

\section{References}

1. Bailyn, John Frederick. 2012. The Syntax of Russian. Cambridge: Cambridge University Press.

2. Baltin, Mark \& Collins, Chris. 2001. The Handbook of Contemporary Syntactic Theory. Massachusetts and Oxford: Blackwell Publishers.

3. Bībele. Vecās un Jaunās Derības Svètie Raksti. 1966. London: The British and Foreign Bible Society.

4. Bihbele. Wezàs un Jaunàs Deribas Swehtee Raksti. 1948. Helsinki: Britanijas un Ahrsemju Bihbeles Beedriba.

5. Cairnie, Andrew. 2013. Syntax. A Generative Introduction. $3^{\text {rd }}$ edition. Chichester: Wiley-Blackwell.

6. Camacho, José A. 2013. Null Subjects. Cambridge: Cambridge University Press.

7. Ceplītis Laimdots, Rozenbergs Jānis, Valdmanis, Jānis. 1989. Latviešu valodas sintakse. Rīga: Zvaigzne.

8. Chomsky, Noam. 1982. Some Concepts and Consequences of the Theory of Government and Binding. Cambridge, Massachusetts: The MIT Press. 
9. Chomsky, Noam. 1988. Lectures on Government and Binding. Pisa Lectures. Dordrecht: Foris Publications.

10. Chomsky, Noam \& Lasnik, Howard. 1993. Principles and Parameters Theory. Jachobs, Joachim, von Stechov, Arnim e. a. (eds). Syntax: An International Handbook of Contemporary Research. Berlin: Walter de Gruyter, 506-569.

11. Chomsky, Noam. 1995. The Minimalist Program. Cambridge, Massachusetts: The MIT Press.

12. Cowper, Elizabeth A. 1992. A Concise Introduction to Syntactic Theory. The Government-Binding Approach. London, Chicago: The University of Chicago Press.

13. Freimane, Inta. 1985. Vienkāršs teikums un tā paplašināšana. Rīga: LVU.

14. Halle, Morris \& Marantz, Alec. 1993. Distributed Morphology and the Pieces of Inflection. The View from Building 20: Essays in Linguistics in Honor of Sylvain Bromberger. Cambridge, Massachusetts: The MIT Press, 111-176.

15. Holvūts, Aksels. 2012. Vispārējās sintakses pamati. Rīga: Latviešu valodas aǵentūra.

16. Kalnača, Andra \& Lokmane, Ilze. 2013. Paradigma morfologijā un sintaksē. Valoda: nozìme un forma 3. Teorija un metodologija latviešu valodniecībā. Rīga: LU Akadēmiskais apgāds, 6-18.

17. Kārkliņš, Jūlijs. 1976. Infinitīva sintaktiskās potences. Rīga: LVU.

18. Kayne, Richard. S. 1991. Romance Clitics, Verb Movement and PRO. Linguistic Inquiry 22, 647-686.

19. Ķiķauka, Pēteris. 1961. Dažas piezīmes par mūsu literāro valodu. Jaunā Gaita, 32, 173-176.

20. Nītiņa, Daina, Grigorjevs, Juris (red.). 2015. Latviešu valodas gramatika. Rīga: LU Latviešu valodas institūts. 2. izdevums.

21. Poole, Geoffrey. 2011. Syntactic Theory. New York: Palgrave.

22. Rizzi, Luigi. 1986. Null Objects in Italian and the Theory of pro. Linguistic Inquiry. 17, 501-557.

23. Růžička, Rudolf. 1999. Control in Grammar and Pragmatics. Amsterdam/ Philadelphia: John Benjamins Publishing Company.

24. Sigurðsson, Halldór Ármann. 1990. Icelandic Case Marked PRO and the Licensing of Lexical A-positions. Working Papers in Scandinavian Syntax (WPSS) 45, 35-82. Lund: Centre for Languages and Literature.

25. Sigurðsson, Halldór Ármann. 1992. Verbal Syntax and Case in Icelandic. Reykjavik: Institute of Linguistics, University of Iceland.

26. Skujiņa, Valentīna. (red.) 2007. Valodniecības pamatterminu skaidrojošā vārdnīca. Rīga: LU Latviešu valodas institūts.

27. The Holy Bible Containing the Old and New Testaments (King James' Version). 1834. Edinburgh: Printed by Sir D. Hunter Blair and M. T. Bruce.

28. Thráinsson (Práinsson), Höskuldur. 2007. The Syntax of Icelandic. Cambridge: Cambridge University Press.

\section{Kopsavilkums}

Formāli nerealizēti komponenti ir abstrakti dziḷās teikuma struktūras elementi. Rakstā iztirzātas pronominālās subjekta nullformas (lielais $P R O$ un mazais pro) ǵeneratīvās gramatikas tvērumā. PRO jeb virsteikuma argumenta kontrolētais nulles subjekts ir elements, kas iedomājams pie nefinītām verba formām. Mazais pro ir implicīts elements, 
kurš atbilst anaforiskam personas vietniekvārdam, kas lietots ar finītām verba formām un atrodas pārvaldītā locījuma pozīcijā. Minētās formas saistītas ar valodas līdzekḷu ekonomijas principu un universālo gramatiku un ir atrodamas visās valodās. Salīdzinājumam izraudzītas divas indoeiropiešu valodas - germāņu (islandiešu) un baltu (latviešu). Rakstā aplūkota iepriekš minēto elementu, cik iespējams, līdzīgā klātbūtne abās valodās, kas ļauj pieņemt, ka starp tām ir zināma līdzība virsējās struktūras ziṇā. Tomēr par spīti kopīgajām iezīmēm ir arī būtiskas atškirīibas, it īpaši saistībā ar īpašỉbas vārdu pārvaldījumu infinitīva konstrukcijās, semantiski tukšă teikuma priekšmeta lietojumu un eksplicītu vietniekvārda lietojumu pavēles izteiksmē. Rakstā galvenā uzmanība pievērsta konstrukcijām, kurās ir lielais $P R O$ un mazais pro, to veidiem un klasifikācijai. Pie infinitīva/divdabja konstrukcijām ar $P R O$ pieskaitāma 1) referenciālā jeb kontrolētā, 2) nekontrolētā jeb patvaļīgā un 3) ekspletīvā konstrukcija. Ar finītām formām ir astoņas mazā pro konstrukcijas: 1) bezpersonas konstrukcija, 2) bezpersonas un ciešamās kārtas konstrukcija, 3) ekstrapozīcijas konstrukcija, 4) pavēles izteiksme/optatīvs, 5) izlaidumkonstrukcija, 6) kontekstuāli reducētas atbildes, parcelāti, 7) skatuves remarkas un 8) eksklamatīvi (izsauksmes) teikumi. Turklāt ir arī marginālākas konstrukcijas, piemēram, 1) bezpersoniska tagadnes divdabja konstrukcija islandiešu valodā, kurai nav tiešas atbilsmes latviešu valodā, 2) bezpersoniska modāla konstrukcija un 3) ergatīvā konstrukcija. 